\title{
Dimensiuni ale timpului în Însemnări de pe manuscrise și cărți vechi din Țara Moldovei, I-IV, un corpus editat de I. Caproșu și E. Chiaburu
}

\author{
Maria Lupu* \\ Facultatea de Litere, Universitatea „Alexandru Ioan Cuza”, Bd. Carol I 11, 700506 Iași, România
}

\begin{abstract}
Despre articol
Istoric:

Primit 7 decembrie 2016

Acceptat 1 ianuarie 2017

Publicat 23 martie 2017

Cuvinte-cheie:

însemnări de pe manuscrise istorie

cultură

mentalitate

Rezumat

Textul de faţă este parte a unor preocupări mai ample, privitoare la evoluția mentalităților în perioada de după secolul al XVI-lea, scopul cercetării de față fiind acela de a identifica și discuta modalitățile în care oamenii epocii respective percepeau timpul.

Cercetarea noastră a avut în vedere materialul oferit de însemnările-cu valoare de sine stătătoare-pe care cititorii le-au făcut pe paginile scrierilor apărute în Moldova, de-a lungul a mai bine de 400 de ani. Principalele instrumente cu care am operat au fost analiza și sinteza, din perspectivă diacronică, de la particular la general, pe cale inductivă.

S-a conturat astfel o imagine a modalităților de percepere și redare a evenimentului, ca element al timpului, și a felului în care timpul devine reperul fundamental al vieții, cel care cuprinde, marchează și generează întreaga realitate.
\end{abstract}

\section{Introducere}

Majoritatea cărților care au fost citite în Țările Române cuprind, alături de textul propriu-zis, sute de însemnări pe filele albe de la început sau de la sfîrşit, care servesc la legatul cărții, pe marginile paginilor sau, cel mai adesea, la sfîrşitul textului. Volumele de documente editate de istoricii ieșeni acoperă o perioadă îndelungată de timp, începînd cu 13 martie 1429 și pînă la mica unire, în 1859; ele pun la dispoziție un material bogat, eterogen și extrem de interesant care capătă o valoare de sine stătătoare și se constituie într-o literatură distinctă, alcătuind o frescă a unei epoci trecute.

Caracterul multidisciplinar al vechilor însemnări le face adevărate izvoare (unice prin specificul lor) pentru cercetarea din varii domenii, pentru cunoașterea istoriei, a limbii și a culturii românești. Această paletă foarte largă de cronici cvasianonime recompune o imagine a universului mental a societății românești din veacurile trecute. Fie că înregistrează încercări de condei, ex-librisuri, acte de donație, notițe personale, diferite fenomene naturale sau istorico-politice etc., multe dintre însemnări sînt puse sub semnul temporalului, fiind datate. Experiența temporală este unul dintre reperele relevante susceptibile să developeze cadrele mentale de bază ale unei societăţi, ale unei civilizaţii, timpul fiind una dintre armăturile felului de a gîndi și de a trăi ale unei societăţi (Nicoară, 1997, p. 54). Astfel, modul de percepere a timpului în corpusul de însemnări marginale este deosebit de relevant în încercarea de delimitare a unor structuri mentale specifice.

\section{Cartea ca dimensiune a timpului}

La un prim nivel al discuţiei asupra timpului aşa cum este el reflectat de însemnări, se situează însăși cartea, apoi chiar însemnarea marginală. Obiect de mare preț, cartea se impune ca dimensiune a eternităţii începînd cu veacul al XV-lea, menţinîndu-se astfel pe tot parcursul epocii studiate. Într-o societate dominată categoric, pînă la un moment dat, de oralitate, scrisul devine, ca în mitul din Phaidros, un leac al

*Adresă de corespondență: marioaralupu@yahoo.com. 
Maria Lupu

uitării și al neştiinței (Platon, 2011, p. 126). Bucurîndu-se de o considerație morală deosebită prin însuși mesajul biblic pe care îl conține, se manifestă credința că volumul/manuscrisul este destinat unei existențe de veacuri (Chiperi, 1996, p. 13). Această certitudine stimulează însemnările, care, o dată încredințate cărților, fixate prin scris, devin o punte spre neuitare, înfruntă timpul în căutarea unui interlocutor în generațiile următoare; de unde și leit-motivul prezent în majoritatea notelor infrapaginale, nevoia de a eterniza clipa trăită - „să să știe”.

De fapt, raportată la timp, cartea evidențiază un sentiment profund religios al oamenilor epocilor respective, conturînd, prin ipostaza ei în percepția comunității, o dimensiune temporală în sens creștin (Radosav, 1997, p. 75). Timpul cărții este de-a dreptul eternitatea: „Stăpîna şi cneaghina Theodora” a dat o Evanghelie mitropoliei din Suceava "neclintit în vecii vecilor, amin” (I, 24) ${ }^{1}$. O dată așezată în strană sau în altar, cartea de cult devine inamovibilă, neafectată de trecerea timpului, perenă (Ofrim, 2001, p. 129). Mitropolitul Teofan donează la mijlocul veacului al XVI-lea, o carte, „ca să-i fie lui amintire pentru nesfirșiții veci” (I, 57). Alteori timpul cărții este perceput ca fiind perfect echivalent cu timpul escatologic, timpul cărții fiind timpul lumii lui Dumnezeu (Radosav, 1997, p. 76). Astfel, ieromonahul Parthenie de la mănăstirea Bisericani cumpără Psaltirea ,ca să fie în chilia mea, pînă cînd va milui Dumnezeu în această lume deșartă” (I, 157). Nu numai donația de carte se face întru veșnicie. Prin contaminare, și acte mai pămîntești, cum ar fi vînzarea cărții respective, se poate face „în veace de vece” (I, 401). Deoarece cartea este „vecinică pomenire” pentru sufletele donatorilor (II, 30), ea reprezintă „cheia” către lumea fericirii veşnice, o legătură între mundan și divin: cei care au contribuit la achiziția unui Chiracodromion sînt „scriși pi patruzăci di fili, spre pomenirea lor și a tot neamul lor, în veacul acesta și în celalalt ce va să fie” (III, 126). Astfel, cărții îi este atașată o dimensiune escatologică, fiind integrată în complexul de credințe, practici și obiceiuri tradiționale menite să asigure mîntuirea sufletului, precum și o cale de consolidare a solidarităţii lumii celor vii cu lumea strămoșilor (Ofrim, 2001, p. 131). Cartea va străbate generațiile, ea fiind cumpărată „ca să fie odoru în veci feciorilor mei și nepoțîlor și strănepoțîlor” (II, 304), cu siguranța că se va bucura de aceeași prețuire. Cartea rămîne egală cu sine de-a lungul timpului, aceleași atribute păstrîndu-le și în secolul al XIX-lea, fiind „,vecinic odor de fericire” (III, 596), contribuind la „,nemuritoare neuitare” (III, 547) a numelui copistului, dar și la „iertarea vecinică” (IV, 453).

Însemnarea marginală este o altă dimensiune temporală. Scrisul reprezintă simbolul eternității. Opus permanent umanului efemer, la nivelul notelor infrapaginale se dezvoltă o tensiune între „mîna de țărînă” (sinecdocă pentru umanitate la modul general) și „,lova veşnică”: „Și mîna care au scris va putrezi în groapă, iar cuvintele vor rămînea în veci, amin” (II, 222). Preotul Vasile Baltag consemnează numele posesorului „spre pomenirii și spre ținere de minte, că oamenii să pitrec, dar sfintele cărți rămîn” (IV, 392). Valoarea scrisului se poate întoarce uneori în defavoarea "păcătoșilor”. Astfel, într-o poezie-meditaţie pe tema morții de la sfirș̦itul secolului al XVIII-lea, păcatele nu vor putea fi nici „dosnicite”, nici tăgăduite, „că sînt scrise prin izvoade/ [...] Să rămîi în vecii” (II, 319).

\section{Simultaneitate}

Notele infrapaginale înseamnă, de cele mai multe ori, activarea memoriei autorului; ulterioare evenimentului, unele dintre ele se află la intersecția a ceea ce grecii numeau mnèmēe (simpla amintire survenită în felul unei afecțiuni) și anamnèsis (amintirea ca obiect al unei căutări active) (Ricœur, 2001, p. 34). Evenimentele actualizate prin consemnarea lor marginală sînt, de cele mai multe ori, datate. Conform Stagiritului, două dimensiuni trasează raporturile dintre aceste evenimente memorate: simultaneitatea şi succesiunea (Ricœur, 2001, p. 186). Textele marginale mizează mai ales pe prima coordonată. Deși însemnările cuprind, de regulă, data—referiri explicite la „timpul cronic”, astral în care se înscriu—, foarte frecvente sînt indicațiile suplimentare pentru a caracteriza mai exact momentul evenimentului. Constatăm o preocupare permanentă de decupaj temporal, de ancorare puternică pe axa timpului.

\footnotetext{
${ }^{1}$ Datorită frecvenței, trimiterile la textele din Insemnări de pe manuscrise și cărți vechi din Țara Moldovei se vor face în felul următor: între paranteze rotunde se va nota numărul volumului cu cifre romane, urmate de numărul paginii cu cifre arabe.
} 
Coincidența evenimentului consemnat cu altele, sociale, istorico-politice, naturale sau personale, se traduce la nivel lingvistic prin diferite sintagme și structuri, adverbiale de cele mai multe ori, toate sinonime cu pe cînd: „în zilele”, „pe vremea”, „pe timpul”, „în domnia”, „(pe) cînd”, „atunci”, prepoziția temporală „sub”; de asemenea, raportul de simultaneitate mai este exprimat prin categorii verbale durative: gerunzii (fiind) sau structuri cu imperfectul „era”. Succesiunea pe axa temporală se exprimă prin „după” sau „după aceea”. Informațiile suplimentare trecute în co-datarea evenimentelor sînt, de fapt, aceleași cu evenimentele în sine, cele care suscită interesul consemnării: domnii, tot felul de situații politico-sociale, fenomene naturale sau foarte personale. Totul este susceptibil de a deveni ancoră în decupajul temporal.

\section{Fundal temporal}

Încă din primele consemnări marginale apare expresia care oferă consistență unui decor politic-domnesc, utilizată constant ulterior - „în zilele”, urmată de titlul domnitorului contemporan. Dacă la 1429 un Tetraevanghel „s-a lucrat [...] în zilele binecinstitorului şi de Hristos iubitorului domn Io Alexandru voievod” (I, 1), patru secole mai tîrziu, o Evanghelie este scrisă de „smeritul ieromonah Irinarh [...] în zilele binecredinciosului și de H(risto)s iubitorului domnului nostru Io Ioann Sandu Sturza boieriu" (III, 600). Domnia, utilizată aproape ca o regulă în datarea însemnărilor mai ales pînă în a doua jumătate a secolului al XVIII-lea, pierde apoi din terenul cucerit, devenind, la începutul veacului următor, o excepție, fără, însă, a dispărea de tot. O posibilă explicație este aceea că în însemnările de început, cînd scrisul nu era accesibil oricui, el era mai ales legat de instituția statală - logofeți, dieci, aceștia raportîndu-se, invariabil, la domn; ulterior, cînd se înmulțesc cărțile, știutorii de carte și, implicit, însemnările, autorii, aparținînd celor mai diverse straturi sociale, nu se mai raportează constant la domnie. Statul devine în textele studiate o expresie temporală personalizată de un monarh (Barbu, 1996, p. 24). Element de stabilitate (aproximativ), domnul este chemat să ofere timpului concretețe, vizibilitate. Totodată, reprezentant al statului, el ia parcă, în posesie un anumit segment temporal: monahul Teofilact cumpăă și donează Palia „pe timpul binecinstitorului domn Ioan voievod” (I, 63). Ca reper în datare, domnia nu este privită ca un dat amorf, ci în dinamica ei: venire în scaun, mazilire, a cîta domnie etc. Se conturează, astfel, o în treagă canava politică, marcată de instabilitatea dată de schimbările dese de domnie, de reveniri la domnie ale aceluiaşi principe: Vasile uricar a scris la 1726, „în zilele preluminatului și înălțatului domnu Io Mihai Racoviţî voievoda, în al unsprăzecele an a înălţatii domnii, la a triia domnie a mării sale” (I, 437).

\section{Repere temporale}

Evenimentele politico-militare (războaie, incursiuni de jaf, ocupații străine), frămîntările social-politice, modificările statutului teritorial, regimul dominațiilor străine (Chiperi, 1996, p. 51) etc., sînt, și ele, utilizate ca reper temporal în însemnări. Se creează astfel un decor politico-social veridic, palpitînd de viață. Simultaneitatea este indicată prin tot felul de situaţii care marchează sensibilitatea colectivă. Un Minei pe luna Aprilie este scris și donat la 1574, „cîndu au venit păgînii turci și tătari și au omorît pe Ion voievod și pe toți ostaşii lui și au cucerit Țara Moldovei mai mult de jumătate” (I, 85). „Vremurile nepaşnice” (I, 307) răsună de jafuri, robiri și omoruri. Un Liturghier este scris „cînd au ars țara și au robit turcii și tătarii” (I, 257); armele se aud pe fundal în desele războaie dintre marile imperii duse pe teritoriu românesc: „Rînduiala călugăririi” este „tălmăcită și scrisă”, printre altele, „în vreamea răzmiriței, nepăcii și al războiului împărăției Rossiei cu împărăția Turcului pentru Țara Leșască și pentru Moldovlahie i proci” (I, 198). Referirile la ocupațiile străine, la venirile și plecările armatelor străine se înmulțesc în cea de-a doua jumătate a veacului al XVIII-lea. O Evanghelie este cumpărată la 1771, „în zili(le) moscalilor” (II, 201), mănăstirea Solca deține, la 1776, o Carte românească de învățăturăa, ,fiind nemții stăpînitori pe aice” (II, 251); iar la 1788, cînd ,în Moldova era oasti moschicească”, s-a născut ,întîie noastră fiică, Todosia” (II, 471). Evenimente dintre cele mai personale sînt notate în ritmul contractelor de pace sau a războaielor europene; moartea părinților este contextualizată: „Tot la acest an 1812, în luna lui avgust, au făcut pace moscalii cu turcii 
și s-au întorsu desp(r)e Dunăre înapoi şi s-au întors în Țara Moschicească, avîndu bătelia cu Bunăpartă, anumi împăratul franțuzesc sau Napolnun (sic!)” (III, 302). Detaliile și spațiul amplu acordat unor astfel de informații ne fac să ne întrebăm care este, de fapt, subiectul însemnării. Exemplele în această direcție sînt nenumărate. Fiecare fapt politic, de importanță mai mare sau mai mică, are ecou în consemnările marginale. Astfel încît, pornind de la datele furnizate ca repere temporale, se poate însăila o imagine plină de substanță a atmosferei istorico-politice din Moldova timpurilor respective.

$\mathrm{Nu}$ doar evenimentele politice constituie puncte de reper în timp. Tot ceea ce marchează, într-un fel sau altul, sensibilitatea umană, devine element de referință. Fenomenele naturale mai deosebite (iernile cumplite și verile secetoase, ploile abundente sau, dimpotrivă, seceta, cutremurele puternice, eclipse și alte fenomene astronomice etc.) se constituie în reper temporal. De asemenea, epidemiile se decantează în cadre temporale în conștiința contemporanilor: „Să să știe că acestu sf(î)nt Minei este a cucernicului ier(o)monahi Ghedeon ot Suvija [...]. Și l-amu cumpăratu în zile(le) preluminatului Ioan Costandin Necolai vodă, cîndu au fost cutremuru mari, cîndu au căzutu mănăstirile după cutremur, ciumă mare. Umbla anul 7246. Eu, monah Ghedeon.” (I, 484).

\section{Valori ale timpului}

De fapt, toate aceste contexte amintite mai sus sînt adaosuri, informații suplimentare, de obicei, pe axa a ceea ce E. Benveniste numea „timpul cronic”. Fie că evenimentul fondator care definește axa timpului este zidirea lumii (de către Dumnezeu), fie că se referă la întruparea lui Hristos, timpul este tot unul „creștinat” de biserică, monopolizat prin calendar, reperul fiind unul biblic (Nicoară, 1997, p. 60). Însemnările marginale sînt datate o bună perioadă în cronologia biblică, în care istoria umanității începe cu Adam: „Anul 6939 < 1431 > martie 24, am sfîrșit” (I, 1). În lumea moldoveană reflectată de consemnările marginale rămîne în uz vechiul calendar iulian, sistemul cronologic folosind, de la mijlocul secolului al XVII-lea, ambele repere: atît de la zidirea lumii, cît și de la nașterea lui Hristos. O Liturghie este cumpărată „în anul de la facerea lumii 7158, iar de la nașterea trupească a Domnului Dumnezeu și Mîntuitorului nostru Iisus Hristos 1659” (I, 228). Această viziune liniară și ireversibilă asupra timpului este specifică creștinismului. Trei momente sînt esențiale pe această axă: facerea lumii, întruparea lui Dumnezeu și judecata finală. Ca durată obiectivă, timpul curge neîncetat în eternitate. Numit de român cu o notă de misticism veac, acesta cuprinde atît timpul istoric cît și veșnicia (Bernea, 1997, p. 147). Cele două fețe ale timpului, clipa și eternul, se regăsesc mai ales în pluralul „nesfîrșiții veci” (I, 56), „veacuri fără de sfirșit" (I, 75). Însemnările reflectă în mod constant o viziune despre un timp care nu este decît un „afluent” al eternității; un oarecare diac Ștefan, care a scris la 1579 o Evanghelie proferează atît un blestem cît și o binecuvîntare, ambele cu valabilitate „în acest veac și în cel viitor” (I, 94); două secole mai tîrziu, este invocată pomenirea unor ,îndurători ai cărţii” ,în veacul acesta și în celalalt ce va să fie” (III, 126). Explicită pentru viziunea temporală creștină este însemnarea de la 1780, constînd în versurile-meditaţie asupra morții. La singular, veacul stă sub semnul istoriei, devenind „acest veac”: „Veacul, lumea să sfîrșaște, județul să găteaște” (II, 320). Încadrat de cele două momente, Facerea lumii și Judecata de Apoi, timpul curge neîncetat, permanent, actualizînd, cu fiecare viață umană însă, posibilitatea veşniciei: „Acolo iasti vesălia ce nespusă / și lumina ce nestrănsă, / unde nu poate nime să privască / și să nu să vesălească / la atîta vesălie / să să dezmierde în vecie" (II, 320). Deci, în însemnări, substantivul plural cu forma veci, precum și locuțiunea adverbială care pornește de la acesta, pe veci(e) semnifică timpul luat în totalitatea sa, trecut, prezent, viitor și încă ceva, eternitatea de după abolirea condiției temporale; la singular, există un acest veac și celălalt veac sau ce va să vie, suprapunîndu-se, primul, lumii acesteia, iar cel de-al doilea lumii de dincolo, care se divide, în imaginarul creștin, în iad și rai. Oricum, veacul se opune vremii, zilelor, sinecdocă a timpului fragmentat și trecător, atașate de regulă unui nume de domnitor, mitropolit sau episcop, care, la un nivel elitist, simbolizează, totuşi, implacabila trecere: în zilele, în vremea, sau chiar în domnia, în timpul.

Remarcăm, constant de-a lungul celor patru secole, dorința de precizie a autorilor de însemnări. Evenimentul consemnat este foarte exact reperat în timp. Primele însemnări înregistrează, uneori, alături de an, 
luna și ziua: scrierea unui Tetraevanghel a început în „aprilie 6 zile”, sfîrșind „al 2-lea an, [...] februarie 3 zile, în anul 6944 <1436>" (I, 2). Cîteodată exprimarea este una astronomică, mai exactă: diaconul Ioan copie alt Tetraevanghel ,în anul $7050<1541>$, luna noiemvrie 23 zile. Era atunci crugul soarelui 22, al lunii 1, numărul de aur 4, temelia 14, epacta 6” (I, 55). O nouă reprezentare a timpului cu ajutorul ceasului începe în mărturiile marginale, o dată cu mijlocul secolului al XVI-lea, cînd scrierea unui manuscris „s-a început în luna septembrie 21 și s-a sfîrșit în luna mai 21 zile, fiind vineri ora 13; vineri s-a și început, la întîiul ceas din zi” (I, 61). Notată sporadic pînă la sfîrșitul secolului al XVIII-lea, din deceniul al nouălea al acestui secol şi la începutul celui următor menţionarea orei devine aproape constantă. De acest „privilegiu” beneficiază mai ales însemnările care înregistrează fenomenele naturale: „Să să știe că la anul 1805 iunie 29, sara la 2 ceasuri de noapte s-au întunecat lumina lunii, fiind întunecare, pînă la 3 ciasuri și giomătate” (III, 191) iar „la anul 1831 ghenarie 11 zile, marți noapte spre miercuri la nouă ceasuri fără 20 minute evropenești sau 4 ceasuri și 8 minute turcești, s-au cutremurat pămîntul” (IV, 37).

Timpul dobîndește mai multă precizie și în alte situații. Ochiul se îndrepta spre arătătorul unui ceas și în momentele intense de venire pe lume a copiilor sau, la polul opus, la moartea unor persoane. Astfel, la 16 iulie 1797 „s-a născut fiul mieu Nicolae, joi la 12 ceasuri și 21 minute ziua” (III, 116), iar preotul Ștefan din Sauceniță „au murit [...] la velet 1819, mai, în joi noapti, spre viniri, la 6 ceasuri” (III, 451). S-ar părea că aceste evenimente extreme, încadrate în riturile de trecere, sînt simţite acut sub presiunea timpului - a unui început, în primul caz, și al sfîrșitului, în al doilea. Încă de la venirea pe lume, omul este pus, parcă, sub auspicii temporale concrete, obiective, neîndurătoare, iar la momentul final, depăşind această lume, trece și din temporalitatea ei devorantă. Aventura individuală se consumă între două repere bine fixate, ora sugerînd, discret, efemeritatea și scurtimea vieții.

Însă notele marginale mai conțin cel puțin o situație în care se face uz de precizia orei, și anume sfîrșirea manuscrisului: „Să se știe că am prescris-o eu, cu slova me, [...] și luănd sfirșit în anul 1807 iul(ie) 17, la 12 ceasuri din zi” (III, 226). Acesta s-ar încadra într-un timp al muncii (intelectuale, în cazul de faţă), individual. Munca depășește concepția medievistă conform căreia este un remediu contra trîndăviei și a nenumăratelor ispite. Timpul începe să preocupe pe cei care scriu pe marginea filelor. Acest lucru este demonstrat de însemnări care evidențiază preocuparea de a calcula orele: „Să să știe cîte ceasuri sînt într-un an: 8760” (III, 191) sau convertirea spaţiului în timp: „[...] De la poalele Bălcanului și pănă la ceialaltă poști iarăşi opt ceasuri, însă 2 suișul, 2 mergere pe podiș, 2 coborîșul și 2 păn-la poști de acole; de la poști apoi și pîn-la Țarigrad mai sînt 9 poști mari, cîte de 12 ceasuri. [...]” (IV, 13). Curgerea timpului este privită pe cadranul concret al orologiului (Barbu, 1996, p. 21). Timpul a căpătat o importanță mai mare în economia existenței (Lemny, 1990, p. 148), tradus prin rîvna cu care se raportează la ceas categorii sociale din ce în ce mai diverse. Totuși, faptul că acest model nu este unul generalizat în însemnări, majoritatea reperelor temporale rămînînd în alt registru, este elocvent pentru evoluția lentă a structurilor mentale ale marii majorități. Chiar fără a marca decisiv întreaga existență, însă ritmul ei s-a înnoit în comparație cu perioada anterioară (Lemny, 1990, p. 153), fiind unul mai precipitat, mai grăbit și, deci, mai preocupat în a surprinde timpul la modul exact.

Timpul natural la care se raportează autorii de însemnări este unul al alternanței ciclice zi-noapte, al anotimpurilor și al muncilor agricole ritmate de această succesiune. Constant, textele marginale consemnează ziua și luna petrecerii evenimentului notat: la 1431 „anul 6939 martie am sfîrșit” (I, 1); patru secole mai tîrziu, „1856 noiemvrie 12, s-au cutremurat pămîntul, noapte la 2 1/2 ceasuri” (IV, 505). Momentele din zi sînt şi ele, surprinse uneori cu foarte mare precizie de notele infrapaginale. Timpul din zi şi noapte nu este uniform, ci este împărțit în subunități bine delimitate. Un cutremur are loc „duminică, dimineața” (II, 304) „feciorul Iordachi” se naște „într-o sfintă marți, pe amiazăzi” (II, 87), o eclipsă de soare are loc „într-o sfintă duminecă, prin prînzul cel mare, aproape de namezi” (II, 141), un incendiu are loc „marți după Paști, pe amiazizî” (III, 12), o eclipsă de soare „au ținut de după prînz pînă seara” (III, 171), un alt cutremur „după amiază zi, adică îndisară, după toacă” (IV, 422), starețul Ioil moare în 1531 ,la miezul nopții spre luni” (I, 48). Uneori și aceste momente sînt subîmpărțite: nașterea fiicei Docița se petrece „sîmbătă spre duminică, după ce au cîntat cucoșii o dată” (I, 544). Vasile Praja moare „marți cînd se revîrsa 
zorile. 1785” (II, 410), un cutremur are loc „noatea pi la cucoși și la revărsatul zorilor” (IV, 15). Alteori reperele temporale țin cont de activitatea umană din acel moment al zilei: „pe cînd se culcă oamenii” (II, 487), „întru o duminică la vreme de masi” (III, 305), „sara cînd șăd uaminiii (sic!) la masă” (IV, 15). Uneori ritmul este cel vegetal: „pe vremea trandafirilor” (III, 454), „pi vremia perjălor” (IV, 87) sau al muncillor agricole: „vara pe vremea seceri” (IV, 36).

Un alt nivel de percepție a timpului care ritmează evenimentele consemnate marginal este un timp al sărbătorii. Fără îndoială, autorii însemnărilor trăiesc într-un timp creștin, marcat de sărbători precum nașterea și învierea Domnului, Sfîntul Gheorghe, Sfinţii Arhangheli Mihail și Gavriil, Buna Vestire (Blagoveșteniile), Rusaliile etc. Timp sacru prin excelență, sărbătoarea este un timp revelat, o ieșire din durata temporală obișnuită a timpului profan. Un timp reversibil și, astfel, recuperabil, mereu egal cu sine, un etern prezent mitic, sărbătoarea este reactualizarea rituală a lui illud tempus, a unui eveniment mitic și religios (Eliade, 1992, p. 76). Fiecare sărbătoare reiterează pentru credincioși reperele esențiale din viața lui Hristos, a Fecioarei și a numeroși sfinți (Nicoară, 1997, p. 64) actualizînd, de fiecare dată, același timp sacru, identic cu sine și cu momentul inițial. În această economie a timpului creștin zilele de post sînt, și ele, de o importanță majoră, devenind un reper important în calificarea unei conduite creștine (Radosav, 1997, p. 221).

Constatăm, în însemnări, că abia la începutul secolului al XVII-lea sărbătorile se constituie în repere temporale. Pînă atunci se preferă un timp obiectiv marcat de ani, zi și lună, arondat domniei și instituţiei ecleziastice - dar la alt nivel, al omului care păstorește, la un moment dat, credincioșii („,̂n zilele lui Petru voievod și ale mitropolitului chir Anastasie al cetății Suceava”, I, 90). O dată ce începe a fi menționat, timpul sacru va constitui un model și, uneori, tipar pentru însemnările ce vor urma. Nu întîmplător, primul text marginal care notează o sărbătoare ca reper consemnează o moarte și îngropăciune, puse sub semnul „marii treceri” în sens creștin: duhovnicul Sava cel Mare, mort la 19 aprilie 1606, a fost îngropat „în ziua Sfintelor Paști” (I, 137), moment simbolic pentru mîntuirea credincioşilor, nu trebuie să trecem cu vederea că mediul din care provine nota infrapaginală este unul monahal. Din ce în ce mai frecvent în secolele următoare, scrieri de manuscrise, nașteri și morți sînt jalonate de reperele luminoase ale calendarului. Chiar în interiorul acestui timp sacru timpul nu este la fel, are valențe deosebite. Astfel, un act de profanare cum este jefuirea mănăstirii de către cazaci are loc în februarie 1676 ,în a doua săptămînă a Postului” (I, 280), o carte este terminată „în Săptămîna 1-a a Postului” (III, 116), iar îngropăciunea tatălui se face „în Sf(întul) și Marile Post, în miercure, a triea săptămînă” (IV, 414).

Uneori evenimentele consemnate aparțin mediului monahal, astfel încît, firesc, unul dintre reperele temporale se circumscrie sacrului. Elocventă în această direcție este însemnarea lui „,ierei Moisă”, care „s-a însurat la Vinere Mare, s-a diaconit la Crăciun, s-a preoțit la Florii” (II, 21). De asemenea, evenimentele care se înscriu în riturile de trecere ale oamenilor (naștere - nuntă - moarte) sînt, și ele, de multe ori puse sub auspiciile unui timp creștin; moartea „mamei Măriuța” are loc la „1759, în cîșlele cele mari, cu două săptămîni înainte de Lăsata Săcului de Postul cel Mare” (II, 86); dascălul Gheorghe se căsătorește dumincă, 17 septembrie 1761, „cînd era pominirea Sfintei Muciniţî Euftimia, iară duminica era a 15 după Rusalii” (II, 114), iar feciorul Manolachi „s-au născutu în luna lui dechemvri 2 zile, la Sfîntul Prooroc Avraam” (III, 306).

La o lectură atentă a corpusului de însemnări în direcția descoperirii unor particularități specifice reperelor temporale, remarcăm faptul că textele care au ca subiect fenomene naturale-cutremure, inundații, furtuni, eclipse—se raportează, regulat, la o sărbătoare creștină. Astfel, „s-au întunecat soarele joi în doî săptămîni după Sfinții Apostoli” (I, 556), ,au dat piatra ce mari” în „a doua săptămînă în postul Sîmpetrului” (II, 58), un incendiu are loc „în zioa de Sf(înta) Troiță” (II, 105), „s-a cutremurat pămîntul la Precuvio(a)sa Paraschiva, adică la Vinirea Mari” (III, 141), „marța, zioa” (III, 143) (ziua de 14 octombrie fiind numită în popor și „Vinerea Mare”, chiar dacă era în altă zi; v. Țighiliu, 1997, p. 44).

Însemnările cu subiect meteo se raportează la sărbători și pentru că acestea, pe lîngă conotațiile metafizice, erau în funcție de anotimpuri, marcînd intervale de timp cu activități și vreme specifice, din viața comunității rurale, de natură agrară sau pastorală (Nicoară, 1997, p. 64), iar vremea nefavorabilă 
împiedică desfăşurarea acestor munci specifice. Pe de altă parte, evenimentele periculoase (cutremure) sau cele astronomice înfricoșătoare (eclipse) sînt puse în legătură cu voința divină, de aici urmînd datarea în sensul sărbătorilor. Remarcăm preferința pentru reperele care înregistrează posturile, lucru firesc într-o lume în care aceste intervale de purificare trupească și sufletească, de sacrificiu, erau efectiv trăite la acest mod.

În concluzie, observăm în notele infrapaginale prezența unor valori temporale dintre cele mai variate. Este prezent timpul ciclic în varianta sa naturală cosmică, dar și în reactualizarea periodică a sărbătorilor; timpul liniar, marcat de curgerea continuă între Geneză și Judecată, timpul profan-obiectiv punctat de acele ceasornicului, timpul sacru creștin. Dacă am aplica modelul lui Krzysztof Pomian (Ricœur, 2001, p. 187), aceste repere temporale s-ar încadra în primele două moduri de a vizualiza timpul, măsurate de orologii și calendare: cronometria (desemnînd ciclurile scurte sau lungi ale timpului care se întoarce, se învîrte în cerc: zi, săptămînă, lună, an (Ricœur, 2001, p. 187) - data din însemnările marginale) și cronologia (timpul liniar al perioadelor lungi, secol, mileniu etc. a căror articulare e punctată în mod diferit de evenimentele fundamentale și fondatoare, Ricœur, 2001, p. 188).

Urmează să discutăm valențele subiective ale timpului, felul în care evenimentele sînt raportate unele la altele, modul în care toate aceste repere temporale (și altele) sînt cumulate în una și aceeași însemnare, modul în care omul se raportează, concentric, la grupul sau grupurile din care face parte.

\section{Cumularea reperelor temporale}

Fie că este timpul natural / cosmic ciclic, fie cel cronic liniar, fie cel al sărbătorii sau cel psihologic, profund subiectiv, de cele mai multe ori aceste ancore temporale ale evenimentului consemnat nu sînt de un singur fel în aceeași însemnare. Observăm de-a lungul epocilor care se succed în textele infrapaginale aviditatea de precizie, de a oferi cît mai multe repere care să fixeze cît mai bine evenimentele pe axa timpului; asistăm la un decupaj temporal exact, la un efort, paradoxal, de a sustrage evenimentul respectiv din curgerea firească a timpului, de a-l imobiliza pe axa temporală, făcîndu-l, astfel, etern pentru posteritate. Astfel încît, aproape toate consemnările marginale care conțin informații referitoare la momentul scrierii sau al evenimentului însemnat se caracterizează prin cumularea reperelor temporale, printr-o simultaneitate caracterizată, la rîndul ei, de o ierarhie care se impune cu pregnanță la o lectură multiplă a corpusului. O dată cu definirea evenimentelor prin poziția lor în raport cu celelalte ne situăm în ceea ce Krzysztof Pomian numește cronografie (Ricœur, 2001, p. 188), aceasta intrînd în sistemele de notare ce se pot lipsi de calendar.

Astfel, începînd cu sfîrșitul secolului al XVI-lea, unele însemnări reflectă, prin reperele temporale alese, o societate puternic ierarhizată. Instituțiile cele mai utilizate în definirea exactă a momentului sînt cea domnească și cea ecleziastică. Călugărul Pahomie scrie cartea „pe vremea mitropolitului întregii Țări a Moldovei, chir Gheorghe, sub egumenul Ghenadie” și „sub Ștefan voievod” (I, 15). Sau, ordinea urmează cursul de la general la particular, descrescător, în cercuri concentrice: un Minei este donat mănăstirii Putna „în zilele binecredinciosului și de Hristos iubitorului domn, Ioan Ștefan voievod, domn al Țării Moldovei, fiul marelui Bogdan voievod, și pe timpul arhimandritului chir Spiridon, în anul $7012<1504>[\ldots .$.$] . Și$ era atunci egumen și ieromonah Pahomie” (I, 31). Monahul și cîntărețul Paisie, cel care consemnează donaţia, se raportează la două autorități: cea domnească, care primează poate și din cauza faptului că domnul inițiază darul, și cea ecleziastică, în cadrul căreia trăiește el însuși. Actul este înscris și în timpul obiectiv, cronic, prin mențioanrea datei: „luna februarie 25”. Componenta laică (domnul, nobilimea) și cea ecleziastică sînt elemente de reper în definirea timpului, mai ales în însemnările din prima perioadă, fiind prezente, însă, și în a doua jumătate a secolului al XIX-lea. Uneori autorul trece domnia și anul, alteori mitropolitul / episcopul / arhimandritul sau altă față bisericească ilustră contemporană, cel mai frecvent însă fiind conjugate aceste ancore temporale: domn, mitropolit și dată. Planurile administrațiebiserică se întrepătrund, uneori, succesiv, coborînd pe treptele ierarhiei: o donaţie se face „în zilele [...] domnului nostru Vasile voievod, și în zilele episcopului Theofan, și în zilele lui Gavrilaș fost mare logo- 
Maria Lupu

făt, pe vremea preotului Petrașco Mediaschi, care era în acea vreme la Bîrnova. În anul $7158<1650$ >, luna mai, douăsprezece zile" (I, 229). Acest fel de notare a timpului este aproape constant în secolele al XVI-lea-al XVII-lea, cu prelungiri și în veacurile al XVIII-lea și al XIX-lea. Uneori sînt cumulate în nota marginală toate fețele bisericești ilustre; arhimandritul Vartolomei transcrie manuscrisul ,în dzilele pre luminatului [...] Ioan Theodor voievoda, și a preasfințitului chir Gavriil mitropolitul Moldovii [...] și a presfinților episcopi chir Ioanichi Romanschi, chir Dosithei Rădăuțchi, chir Inochenti Hușschi, fiind igumen în mănăstire Putna chir Pahomii[...]” (II, 107). Bineînțeles că cel care consemnează „de cînd am vinit de la mitropolie din Iaș aici în Pobrata” se raportează la lumea din care face parte, descriind astfel cercuri concentrice: „în zilele mării sale lui Mihail vodî, mitropolit fiind chir Gheorghie, egumen fiind chir Vartolomei. L(ea)t 7231 iuli 15.” (I, 425).

În a doua jumătate a secolului al XVII-lea apare, pe lîngă alte referințe, și contextualizarea de natură personală. Mitropolitul Dosoftei donează o carte în „7195, în Striju, fiind în bejenie printre străini din cauza vremurilor nepașnice" (I, 307). Simultaneitatea evenimentelor consemnate cu altele, de natură personală, devine mai frecventă în secolele următoare. Un Octoib este cumpărat de cel care face și însemnarea „la domnia preînălțatului domnului nostru Io Ioan Theodor voievoda, fiind rînduit cu slujba agiutorinții la Putna, în anul let 7269 <1761> fev(ruarie) 5" (II, 106); un cutremur are loc la 16 octombrie 1774, „și cînd s-au cutremurat pămîntul eram în gios cu vădrăritu” (II, 228). Lectura unui Hronograf se face în zilele lui Grigore Calimah și a mitropolitului Gavril, la 1768, „, eri eram preot la sfînta băsărică ce să prăznuiește Sfinții Părinți Athanasiia și Chiril, aice în Iaș” (II, 176). Rețin atenția informațiile personale despre starea de sănătate: un Sinopsis este citit „cînd eram la Cretești, în doftorii” (II, 208), o carte este legată la 1800, „cînd am fost bolnav la un picior” (III, 53), iar cutremurul din 24 aprilie 1834 este asociat cu „stricarea stomahului” din acea zi (IV,96). Alteori aflăm vîrsta autorului în anumite momente importante. Manolache Cîrje termină de scris cartea la 20 noiembrie 1811 seara, la „7 ceasuri de noapte, [...] fiind în vrîstă de 20 de ani” (III, 287), iar uneori evenimentul însemnat este numai un motiv pentru a informa despre viața personală. Cutremurul din 6 februarie 1812 are loc „cînd cetem eu sara, eram cu mătușa și cu mama în casă. Umblu la scănțălarie (sic!) ispravnic amu. Și Gheorghie Liga samiș” (III, 568).

Evenimentele de natură istorico-politică se asociază, și ele, altor repere temporale. Acestea creează un decor realist pentru faptul consemnat, oferind în același timp substanță și senzația unei lumi veridice, în mișcare. Paradoxal, în ciuda faptului că decupajul temporal este foarte exact, ceea ce „țintuiește” parcă evenimentul pe axa temporală, îl imobilizează, aceste informații suplimentare referitoare la lupte, ocupații străine, răzmerițe etc. creează un decor dramatic zgomotos și mobil. Prim planul însemnării marginale este dublat de un plan secund pulsînd de viață, dinamic. Spre deosebire de cazurile în care referința se făcea la domnii și oblăduiri ale mitropoliților, ceea ce induce o impresie statică, jafurile tătarilor, bătăliile dintre turci și ruși, turci și nemți, „vreamea răzmiriței, nepăcii și al razboiului” (II, 198) creează o lume în desfășurare, plină de viață și moarte. Acest decor dramatic face ca lumea reflectată de însemnări să palpite, creează un tablou tridimensional în care, sinestezic, coexistă vizualul cu auditivul, fiind resuscitat ceea ce pare a fi imobilizat în timp. Logofătul Manolachi, ginerele preotului Andrei, citește, la 1771, Cartea românească de învățătură „pă vreame dea răzmiriță, cînd au venit muscalii ș-au luat Hotinul ș-au venit la Ieș și di la Ieș au mersu de-u bătut turcii la Răbîia și dea acolo o samă dintr-înşii au mersu la Focșani și di la Focșani au mersu de-au bătut toamna Galații [...]” (II, 202), detaliile continuînd din belșug. Și alte informații participă la crearea imaginii unei lumi în care pîndesc pericolele, în care insecuritatea devine principalul cadru de existență: schimbarea tîrgului la Cernăuți, la 1772, este un motiv de a adăuga: „,̦i era staroste la Cernăuț dum(nea)lui paharnicul Imbou și d-lui starostele Ilie Herescu, și era tălhari la ulițe, pîn codri, și făc(e) multă ucidere” (II, 209).

Acumularea de date de tot felul, care ajută la precizarea cu exactitate a momentului evenimentului consemnat, devine uneori heteroclită, juxtapunînd informații variate. De asemenea, cîteodată localizarea temporală a evenimentului este mult mai întinsă decît evenimentul în sine, astfel încît ne întrebăm ce primează, care este, de fapt, subiectul textului marginal. Rînduiala călugăririi este tălmăcită:

- „în zilele binecredincioasei și singură stăpînitoare a toată Rossie și Moldovlahiei întîie stăpînitoarei, 
marei doamnei noastră Imperatrîți(i) Ecaterinei Alecsievni(i)

- și a preaiubitului fiiului și moștenitoriului ei, binecredinciosului domnului țesarevici și marele cneaz Pavel Petrovici,

- în vreamea răzmiriței, nepăcii și al razboiului împărăţiei Rossiei cu împărăția Turcului pentru Țara Leșască și pentru Moldovlahie i proci,

- fiind și ciumă mare, mare în țară, la Iași, la Botoșani și al alte locuri.

- Iară mitropolit țărăi fiind preosf(i)nția sa chir Gavriil

- și episcop Rădăuților preosf(i)nția sa chir Dosithei” (II, 198).

Am ales această dispunere paginală pentru a evidenția multitudinea ancorelor temporale, din dorința de a crea un tablou amplu, de a contextualiza, de a oferi cît mai multe date care „rotunjesc” informația inițială, oferind astfel o mostră din lumea contemporană autorului. Fenomenele naturale sînt, de obicei, surprinse cu o precizie deosebită, fixate temporal aproape de fiecare dată în calendarul religios, dar la care se adaugă, cu generozitate, o serie întreagă de alte repere. Cu rigoare științifică, se notează: „Să să știe cîndu s-au cutremuratu pămîntul

- în cîşligile Crăciunului,

- iarna,

- în luna lui ghenar,

- în 11 zili marţi sara

- ca la 3 ciasuri din noapte, spre miercuri,

- anul 1838,

- fiind domn în pămînt Moldovei măria sa Mihail Grigoriu Sturza voievodul

- și mitropolitul Veniaminu preasfințitu

- și episcop Romanului Meletie” (IV, 178).

Cercurile concentrice ale timpului sînt situate și la un alt nivel: nașterea „feciorului Iordachi” are loc „în zilele preluminatului domnului nostru și stăpînitoriu a toată Moldova Ion Teodor voievod, în domnia întăia, în luna lui martie în 23, într-o sfintă marți, pe amiazăzi, în leat 7267 <1759>” (II, 87). Obiectivitatea timpului este fracturată de calificativul „sfîntă”, care pune întregul eșafodaj temporal sub semnul unei sensibilități religioase cu care ne-am obişnuit.

La început, însemnările consemnează mai obiectiv timpul (data, domnia, mitropolitul). Pe măsură ce înaintăm, timpul se colorează afectiv iar reperele se înmulțesc. Posibilitățile de combinare ale reperelor temporale sînt nenumărate. Dată, domnie, mitropoliți, egumeni, sărbători, posturi, evenimente personale, ocupații străine, războaie, răzmerițe, cutremure, epidemii etc. - toate sînt combinate și cumulate pentru a conferi precizie. Creînd impresia simultaneității prin mărcile specifice și coordonate copulativ prin conjuncția „și” sau „iar”, această acumulare extraordinară de repere temporale dovedește acribia cu care autorii de însemnări speră să învingă, pentru o clipă, efemeritatea; multitudinea de repere este chemată pentru a „bate în cuie” pe axa timpului un anumit eveniment, în iluzia (conștientă) că este salvată clipa. De asemenea, timpului fizic, obiectiv (an, zi, dată) îi este asociat timpul psihologic, colorat afectiv (selecția subiectivă a evenimentelor la care se raportează, surprinderea unor evenimente personale). Timpul nu este pentru autori unul omogen, cu aceleași valențe, ci, dimpotrivă, are calități diferite. Timpul individual, personal, se dizolvă într-un timp social, al destinului comun (Bernea, 1997, p. 168). Timpul este, de asemenea, unul viu, concretizat în diferite acte individuale sau mai generale. În însemnări timpul se remarcă printr-o foarte mare concretețe, prin traducerea lui în diferite evenimente (sociale, personale). Astfel, timpul capătă propria individualitate, nu este o abstracțiune, se desprinde din amorful obiectiv și devine încărcat calitativ.

Nici la nivel religios (popular sau nu), timpul nu este la fel. Timpul este activ, are anumite însuşiri, pozitive sau negative (Bernea, 1997, p. 208). Astfel, o însemnare cuprinde o înșiruire de zile ale unor luni: „mart(ie) 4 și 20; apr(il) 3 și 20; mai 6 și 20 [...]” în care „nu-i bine să facă cineva început ori la ce lucru, că va ave pagubi și întîmplări de pacosti, adică supărări și primejdie în urmare acelui drum sau lucru" (II, 138). Deci există ceasuri rele, influența timpului se poate concretiza în consecințe distructive. Pe de altă 
parte, influența pozitivă, creatoare a timpului reiese din altă însemnare: „însămnari pentru celi 12 viniri ce esti bine să le postiască, să nu mănînce creștinu pești, într-aceli viniri, cum nici altă nimică pînă după svințire soarelui, și își va faci vecernie și pacevernița care îi vor fi de mare folos, și sufletești și trupești” (III, 474), urmînd enumerarea vinerilor respective. Oricum, în lumea creștină vinerea are valențe pozitive.

\section{Concluzii}

Din punct de vedere al plasării în timp a evenimentelor notate, însemnările corpusului editat de Ioan Caproșu şi Elena Chiaburu se împart, dihotomic, în consemnări marginale care notează detaliile temporale și consemnări care nu precizează data. Lectura textelor din prima categorie impune cu evidență faptul că, uneori, pe lîngă notarea obiectivă a datei, autorul oferă tot felul de informații adiționale care devin ancore temporale pentru evenimentul consemnat. Aceste elemente de referință aparțin timpului ciclic, cosmic, evident în alternanța zilelelor și nopților şi în succesiunea anotimpurilor; un timp cronic, obiectiv, măsurat de acele ceasornicelor - precizia orei devenind constantă uneori. În curgerea liniară și ireversibilă dinspre Facerea Lumii înspre Judecata de Apoi-momente cheie în unele însemnări-timpul sacru al sărbătorii irumpe și reiterează, de fiecare dată, același moment sanctificat din istoria creștinismului. Frecvența deosebită a „Sfintelor Paști”, a Crăciunului, a Blagoveșteniilor, a unei multitudini de personaje din panteonul creștin, a posturilor ca puncte de referință în ancorarea temporală definește o mentalitate profund religioasă. Totul se poate transforma în reper temporal: domnia, „păstorirea” diferiților prelați, evenimente istorico-politice care au impresionat sensibilitatea colectivă, fenomene naturale cu aceeași caracteristică, evenimente personale, familiale, intime etc. Interesantă este cumularea acestor elemente de referință, uneori încadrarea temporală fiind atît de detaliat prezentată încît depășește cu mult spațiul acordat fenomenului notat. Precizia fiind o constantă a însemnărilor, asistăm la încercarea asiduă de a surprinde momentul, de a transcende dincolo de efemer, de a salva un crîmpei din viaţa personală sau colectivă din curgerea timpului. Multitudinea reperelor, raportarea la carte ca simbol al perenității, însăși consemnarea marginală cu varii subiecte dovedesc tocmai această încercare de a învinge, într-un fel, timpul (deși peste tot apare leit-motivul mîinii de țărînă, sinecdocă a condiției umane supuse timpului și, astfel, morții), de a-l imobiliza într-un crîmpei de viață, de a transmite mai departe, peste generații, un suflu din viaţa acestor autori de însemnări.

\section{Bibliografie}

\section{A. Izvoare}

Însemnări de pe manuscrise și cărți vechi din Țara Moldovei, corpus editat de Ioan Caproşu şi Elena Chiaburu, vol. I-IV, Casa Editorială Demiurg, Iași, 2008-2009.

\section{B. Literatură de specialitate}

Barbu, D. (1996). Scrisoare pe nisip. Timpul și privirea în civilizația românească a secolului al XVIII-lea, Antet, București, p. 24-121.

Bernea, E. (1997). Spațiu, timp și cauzalitate la poporul român, Humanitas, București, p. 147-208.

Chiperi, M.A. (1996). Vechi însemnări românești ca izvor istoric, Silex, Casă de Editură, Presă și Impresariat, București, p. 13.

Eliade, M. (1992). Sacrul și profanul, traducere din limba franceză de Rodica Chira, Humanitas, București, p. 76.

Lemny, Șt. (1990). Sensibilitate și istorie în secolul XVIII românesc, Editura Meridiane, București, p. 148-153.

Nicoară, T. (1997). Transilvania la începuturile timpurilor moderne (1600-1800). Societate ruralăşi mentalităţi colective, Presa Universitară Clujeană, p. 54-64.

Ofrim, Al. (2001). Cheia și Psaltirea. Imaginarul cărții în cultura tradițională românească, Editura Paralela 45, p. $129-131$.

Platon (2011). Phaidros, în românește de Gabriel Liiceanu, Humanitas, București, p. 126

Radosav, D. (1997). Sentimentul religios la români. O perspectivă istorică (sec. XVII-XX), Editura Dacia, Cluj-Napoca, p. 27131.

Ricœur, P. (2001). Memoria, istoria, uitarea, traducere de Ilie Gyurcsik și Margareta Gyurcsik, Editura Amarcord, Timișoara, p. 34-188.

Țighiliu, I. (1997). Societate și mentalitate în Țara Românească şi Moldova, secolele XV-XVII, Paideia, București, p. 44. 